\title{
A Tertiary Study and Social Network Analysis on Agile Software Development Methodology
}

\author{
Çevik Yazılım Geliştirme Metodolojisi Üzerine Bir Üçüncül Çalışma ve Sosyal Ă̆ Analizi
}

\author{
Egemen BAYRAM 1 (iD), Buket DOĞAN ${ }^{1}$ (D), Volkan TUNALI ${ }^{2}$ \\ ${ }^{1}$ Marmara University, Faculty of Technology, Department of Computer Engineering, 34722, \\ Kadikoy/ISTANBUL \\ ${ }^{2}$ Maltepe University, Faculty of Engineering and Natural Sciences, Department of Software Engineering, 34857, \\ Maltepe/ISTANBUL
}

\begin{abstract}
In recent years, there has been an increasing interest in research and application of agile software development. In academic literature, the number of systematic literature reviews (SLRs), systematic mapping studies, and unsystematic reviews has also increased. One of the aims of this article is to create a tertiary study of SLRs on agile software development research topics between 2013 and 2018. Our second goal is to provide an in-depth analysis with data including reference, author, institution, etc. belonging to this tertiary study, and to provide an in-depth analysis for software engineering researchers and practitioners to reveal the relationships of developments in this field. We applied a two-stage research method within the scope of the study. First, we obtained and examined the systematic literature reviews published in the field of agile software development from Web of Science, Science Direct, Scopus, and IEEE academic databases. Second, we visualized the publications examined within the scope of the tertiary study, and revealed the relationships between publications, researchers, institutions, publication sources, and countries with VOSviewer and Gephi social network analysis tools. The findings obtained as a result of the study can be summarized as the fact that developing countries have more studies on the subject, the cited publications are mostly from developed countries, contrary to what is expected, distant countries are more in cooperation, and the number of citations is not directly proportional to the number of publications.
\end{abstract}

Keywords: Tertiary Study, Agile Software Development, Social Network Analysis, Systematic Literature Review, Bibliometric Analysis.

Öz

Son yıllarda çevik yazılım geliştirme üzerine araştırma ve uygulama geliştirmeye olan ilgi artmaktadır. Akademik literatürde de birçok sistematik literatür taramalarının (SLT), sistematik haritalama çalışmalarının ve sistematik olmayan incelemelerin sayısı da artmıştır. Bu makalenin amaçlarından biri, 2013 ve 2018 yılları arasında çevik yazılım geliştirme araştırma konuları üzerine SLT'lerin üçüncül bir çalışmasını oluşturmaktır. İkinci hedefimiz, referans, yazar, kurum vb. bu üçüncül çalışma ve yazılım mühendisliği araştırmacıları ve uygulayıcıları için bu alandaki gelişmelerin ilişkilerini ortaya çıkarmak için derinlemesine bir analiz sağlamaktır. Çalışma kapsamında iki aşamalı bir araştırma yöntemi uyguladık. İlk olarak, çevik yazılım geliştirme alanında yayınlanmış sistematik literatür taramalarını Web of Science, Science Direct, Scopus, ve IEEE akademik veri tabanlarından elde ederek inceledik. İkinci olarak ise üçüncül çalışma kapsamında incelenen yayınları VOSviewer ve Gephi sosyal ağ analizi araçları ile görselleştirilerek, alandaki yayınlar, araştırmacılar, kurumlar, yayın kaynakları, ve ülkeler arasındaki ilişkileri ortaya koyduk. Çalışma sonucunda elde edilen bulgular gelişmekte olan ülkelerin konu hakkında daha çok çalışması olması, alıntılanan yayınların ise çoğunlukla gelişmiş ülkelerden olması, beklenenin aksine yakın ülkelerin değil uzak ülkelerin daha çok iş birliği içinde olması, çıkarılan yayın sayısı ile alıntılanmanın doğru orantılı olmadığı şeklinde özetlenebilir.

Anahtar Kelimeler: Üçüncül Çalışma, Çevik Yazılım Geliştirme, Sosyal Ağ Analizi, Sistematik Literatür Taraması, Bibliyometrik Analiz.

\section{INTRODUCTION}

Any scientific research usually begins with a literature review to gain a good understanding of the existing research and the discussions relevant to a particular topic or area of study. A systematic literature review is a powerful tool for identifying, evaluating, and interpreting all current research related to a particular research question or subject area. Its main objective is to provide an unbiased assessment of a research topic using a reliable, rigorous, and auditable methodology [1]. In addition, a systematic literature review provides a repeatable research method with sufficient detail that it can be reproduced by other researchers when properly followed and implemented. Besides, detailed documentation of the steps performed within the systematic literature review allows for an in-depth evaluation of the work carried out [2]. 
Researchers who want to carry out a systematic literature review need thoroughly to examine all available literature on the subject they are interested in. Individual studies that are subject to a systematic review are called primary studies. A systematic literature review that considers these primary studies is called a secondary study. When these systematic literature reviews are systematically scanned by a higher level methodical literature review, then it is called a tertiary study [2].

In this study, we wanted to determine the recent trends in agile software development by analyzing the related literature by using the tertiary study methodology as our primary tool. After the Agile Manifesto was declared by a group of software development experts in 2001, lots of research have examined the subject of agile software development and produced various publications on it. Agile software development applications such as Extreme Programming (XP) and Scrum have been increasingly adopted to address the challenges of volatile business environments where markets and technologies have been evolving highly rapidly. As seen in Figure 1, number of scientific studies on agile software development, which has a history of about two decades, has been increasing steadily every year.

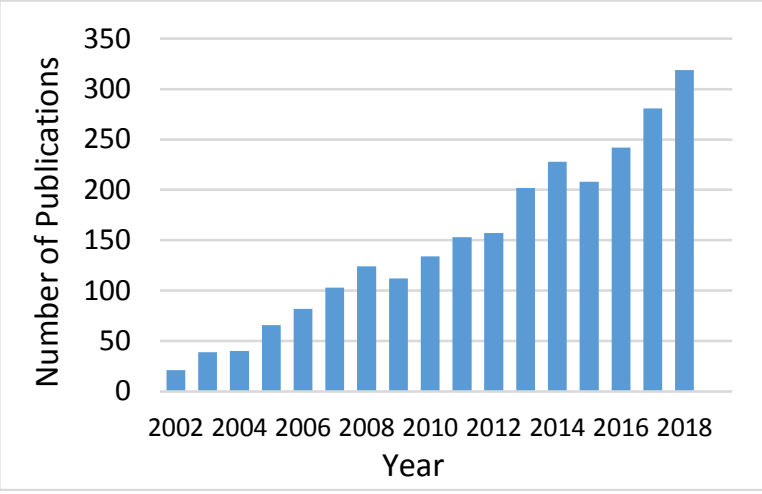

Figure 1. Number of publications on agile software development indexed in Scopus Database.

The second tool we used to analyze literature on agile software development was Social Network Analysis (SNA), which is the process of examining social structures using networks and graph theory. It characterizes network structures in terms of nodes that correspond to some entities, and edges or connections that connect these entities [3]. Applying SNA tools and techniques on the secondary studies, we revealed and analyzed the connections among authors, institutions, and countries of the publications under our consideration.

This paper is organized as follows: In Section 2, we provide some literature review on recent related studies. Section 3 explains the details of our methodology. In Section 4, we present our findings and discuss about them. Section 5 concludes the study and provides some future directions for further research.

\section{RELATED WORK}

The term "Agile" is an umbrella concept that includes methods such as Scrum, eXtreme Programming (XP), Crystal, Feature Driven Development (FDD), Dynamic Software Development Method (DSDM), and Adaptive Software Development [4, 5]. Agile Methodologies is a suite of software development methods based on iterative and incremental development. The four main characteristics that are fundamental to all agile methodologies can be summarized as: adaptive planning, iterative and evolutionary improvement, rapid and flexible response to change, and encouraging communication.

Despite agile methods are developed for small and independent projects, they attract large projects and companies due to their benefits. Larger projects are known with a need for more coordination in comparison to small projects. Therefore, in larger projects how to cope with the coordination within teams, departments, users, and even stakeholders occupies the top priority to solve. Regardless of this coordination related challenges, large scale projects are increasingly adopting agile methodologies [6].

We see that the first studies on the agile method focused on issues related to the adoption of these methods [7]. Team dynamics (such as trust, selforganization, and communication) [8], results of testdriven development [9], post-adoption issues [10], and the difficulties of implementing agility in distributed environments $[11,12]$ are also included in the literature. In addition to primary studies on agile methods, there are also a significant number of secondary studies in the form of literature reviews and mappings published in this area over the past decade [4].

Case studies of current systematic literature reviews on agile software development can be shown as follows. In Jalali and Wohlin's study, it is revealed that the main difficulties for global software development and agile integration between 1999-2009 are differences in time zones, communication, level of trust, knowledge in management, culture and difficulties for personnel [13].

Silva et al.'s study focused on integrating CMMI with agile methods. In this study, they argued that CMMI can be used to reduce the efforts to reach levels 2 and 3 , and even showed that there are reports showing that the application of agile methods will achieve level 5 [14].

Methods that provide bibliometric analysis, such as social network analysis, are widely used to provide a comprehensive structure and visualization of a particular literature knowledge structure. In such studies, the data to be analyzed in the social network may also be data groups such as authors, references, 
and institutions emerging in the systematic literature studies or the tertiary study in which systematic literature studies are examined $[15,16]$.

The purpose of any tertiary study is to reveal important researches, subject areas, orientations, knowledge status, important researchers, institutions, and information exchange structure in a particular field [2, $5,17]$. Since the amount of data generated during these studies is enormous, social network analysis offers great opportunities for better understanding, visualization, and in-depth analysis of current relationships [16, 18]. In this current study, subjects, researchers, and reference relationships in the systematic literature studies between 2013-2018 on Agile software development are revealed, summarized and visualized, and the current situation, hidden patterns and future trends in this field are revealed.

\section{MATERIAL AND METHOD}

\subsection{Research Questions}

The research questions of our tertiary study were determined by adapting the research questions by Kitchenham et al. [17] to cover the publications between 2013 and 2018. Accordingly, the research questions of our study are as follows:

RQ1: How many SLRs were published related with agile software development between 2013 and 2018 ?

RQ2: Which subjects of agile software development were focused on in SLR studies published between 2013-2018?

RQ3: Which researchers, institutions, and countries are most active in agile software development SLRs between 2013 and 2018 ?

RQ4: How is the social network structure of countries and institutions in SLRs between 2013 and 2018?

\subsection{Tertiary Study's Search Process}

In the first stage, we conducted a literature review for our tertiary study to identify and analyze existing Systematic Literature Reviews (SLR) related to Agile Software Development (ASD). We followed and applied the guidelines proposed by Kitchenham et al. [2] for the tertiary study conducted within the scope of this study. The data of an SLR in this context also served as the basis for social network analysis that we performed subsequently.

In order to select the scientific databases, we considered the databases that contain publications in the fields of Computer Engineering, Software Engineering, and Computer Science. As a result, we selected Scopus, Science Direct, IEEE, and Web of Science databases to search. As stated in the studies of SLRs published in previous years, these databases cover a significant part of the publications on agile software development.

While determining the search texts, we took into consideration the texts used by Kitchenham et al. in [17] and we adapted them to the scope of our study.
We carried out searches on determined texts on title, abstract, and keywords as seen in SLRs published in previous years. Examples of the search strings specified are given in Table 1.

Table 1. Examples of the search strings specified when searching the scientific databases.

\begin{tabular}{|l|}
\hline Search String \\
\hline "agile" AND "review of studies" \\
\hline "agile" AND "structured review" \\
\hline "agile" AND "systematic review" \\
\hline "agile" AND "literature review" \\
\hline "agile" AND "literature analysis" \\
\hline
\end{tabular}

We determined the search interval as between January 2013 and December 2018, and we researched the publications (research articles and conference papers) published in the last 6 years. We performed our searches on each database specifically on March 16, 2019 for Web of Science, March 18, 2019 for IEEE, and March 30, 2019 for Science Direct and Scopus.

We found 896 publications in total in the searched databases for each search string. We eliminated duplicate publications and the remaining 409 publications were subjected to the inclusion/exclusion criteria at the next stage. We applied the following inclusion/exclusion criteria:

\section{Inclusion:}

- Being within the scope of agile software development,

- Including a systematic literature review,

- Availability of full text.

\section{Exclusion:}

- Not concentrating on software project management,

- Using agile methodologies as tools, not goals.

After the review for the inclusion/exclusion criteria, 281 publications were eliminated. The remaining 118 publications were examined according to the quality criteria in the next stage. The quality criteria to be applied were chosen as the DARE quality criteria used in tertiary studies $[19,20]$. After the evaluation stage made according to the quality criteria, we also eliminated 19 publications with under 2 points. The bibliographic data of five publications that were not indexed in the Scopus database were not available, thus the remaining 94 publications formed the actual dataset of this study for SNA.

\subsection{Social Network Analysis}

The introduction of the sociogram concept in 1937 by Moreno [21] can be considered as the beginning of SNA (Social Network Analysis) in the social sciences. Sociograms are a representation, where interpersonal relationship patterns can be studied as larger social clusters [3]. The development of social network analysis tools like UCINET, PAJEK, NodeXL, and Gephi with the development of computer technology 
has advanced the progress of social network analysis. These social network analysis tools have become attractive for different disciplines such as engineering, primarily sociology, anthropology, economics, and political science.

In this study, we used both VOSviewer [22] and Gephi [23] for SNA and network visualization. VOSviewer is a software tool designed specifically to create and visualize bibliometric maps and to create graphic representations of maps of scientific papers [22]. VOSviewer can create clusters of the nodes in networks. The algorithm used for clustering has several parameters that can be tuned like resolution and minimum cluster size. The resolution parameter determines the level of detail of the clusters and it cannot get a negative value. We used the default value of 1 of the resolution parameter in our research. Gephi is Java based open-source network analysis and visualization software. It can view complex networks in real-time very efficiently [23].

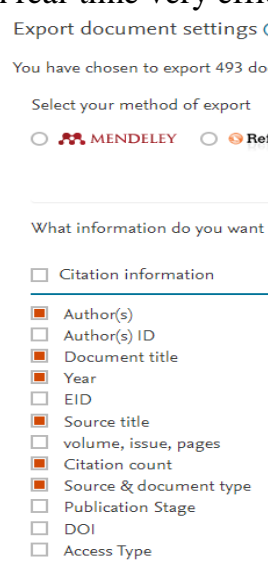

\subsection{Data Preprocessing}

In order to perform analysis with VOSviewer software, a data file in CSV or RIS format is required. On the English language publications in the Scopus database, with the 2013-2018 year filter, under the title-abstractkeyword tab, the search was carried out with the help of the query "agile and ("analysis of research" or "literature analysis" or "literature review" or "literature survey" or "meta-analysis" or "past studies" or "review of studies" or "structured review" or "subject matter expert" or "systematic review")". As a result of the search, 94 of the 99 publications determined at the beginning were reached and bibliographic data (authors, name of the publication, publication year, source title, number of citations, source type, institutions/countries of the authors, keywords, and resources in the publication) were saved in CSV format for further analysis with social network analysis. The screen of search is shown in Figure 2.

Figure 2. Data search screen in CSV format in Scopus database.

In the data downloaded from the Scopus, the inconsistency problems in the fields such as author name and institution name were resolved at the preprocessing stage. For example, while authors with more than one name can use a single name in some publications, the same person can use more than one name together in a different publication. Additionally, the same conference event can be expressed with different names. Since social network analysis tools cannot detect and automatically resolve this situation, we performed a meticulous pre-processing and deduplication on the data. As a result, the number of publications in our final dataset was reduced from 4,914 to 3,697 after the preprocessing phase.

\subsection{Citation Analysis and Bibliographic Coupling}

Citation analysis shows the effects of publications, authors, sources, institutions, and countries on the subject through the number of citations [24]. It determines network relationships according to the number of publications the authors cite each other. It not only takes place on the basis of publication, the relations can also be visualized on the basis of the author, the institutions the authors are affiliated with, the countries, and the source of the publication (scientific journal, book, or conference). Newer publications are disadvantageous in this analysis compared to older ones, since earlier publications will have more citations than newer ones.

Bibliographic coupling was introduced in the literature by Kessler in 1963 [25]. This analysis matches the publications that share common references. It is a useful approach that can be used in all fields of research, as it helps the researcher find related publications in the past.

\section{RESULTS AND DISCUSSION}

\subsection{Tertiary Study Results}

The aim of the first research question investigated within the scope of our study was to determine how many SLRs related to agile software development were published between 2013-2018. A total of 94 publications were examined, $39(41 \%)$ of them were research articles published in scientific refereed journals, and $55(59 \%)$ were papers presented at various scientific conferences and/or congresses. The 
distribution chart of these publications according to the years they were published is shown in Figure 3.

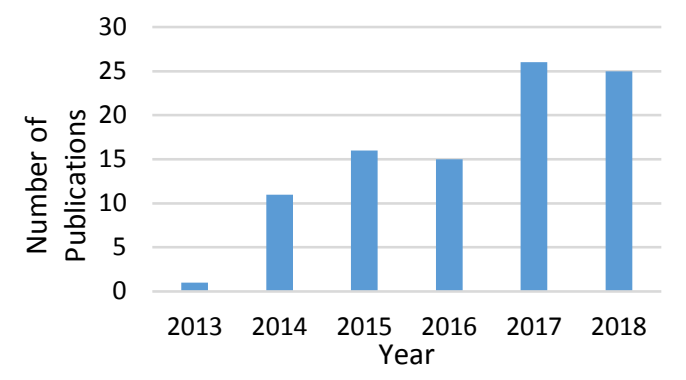

Figure 3. Distribution of publications according to the publication year.

The sources of the 94 publications examined within the scope of the tertiary study can be seen in Table 2 . While creating the table, sources with more than one publication were included. Information and Software Technology journal, ACM International Conference Proceeding Series, Lecture Notes in Computer Science are the top three places with the highest number of publications.

The purpose of the second research question investigated within the scope of the study was to determine which subject areas were researched with agile software development between 2013-2018. The main subject areas that 94 publications focused on are shown in Table 3. As seen in Table 3, Agile practices, Agile and management areas and Agile and global or distributed software engineering issues are the most common issues in publications.

One of the aims of the third research question investigated within the scope of the study was to determine which researchers were most active in agile software development SLRs between 2013-2018. There are 3 publications of 6 authors out of 270 authors in 94 publications examined and they are shown in Table 4.

\subsection{Citation Analysis}

Our dataset consists of publications by 270 researchers and from 133 institutions worldwide. Total number of citations of these publications is presented in [20].

In this study, we present the social network diagram of the institutions and the universities in Figure 4 and 5, respectively. The sizes of the nodes in the figures are proportional to the number of citations. We also present the citation clusters of the institutions and the universities in Table 5 and 6 , respectively.

As can be seen in Figure 4 and 5, the selection of a short time interval for analysis negatively affected the number of connections due to the limited time for publications to cite each other. Despite this, although the analysis included a limited number of networks, it is noteworthy that if there were more than one institution belonging to the same country, there would be more than one institution belonging to a country in the same cluster. This means that researchers are more interested in publications published in their own country, and it is an unexpected result in an era of increasing globalization.

In the citation analysis for instutions, we see that the institutions that were strong according to the connection power had a success above the average compared to the institutions that did not have a relationship in the related figure. Another reason for the low number of links may be the abundance of resources to be used, since agile software development is a very popular topic, because even if the publications do not refer to each other, it was seen that they should not be underestimated in the number of citations.

We also analyzed our data on the basis of the country of the authors, with a total of 33 countries. VOSviewer results of country-level citation analysis can be seen in Figure 6.7 out of 11 countries that provide a connection between clusters are from Europe, that means the authors refer to each other more in Europe. It can be seen that Brazil does not belong to any cluster and connects the red cluster (Chile, Peru, Spain, UK) to green cluster (Iran, Malaysia, Slovenia) as a kind of bridge.

\subsection{Bibliographic Coupling Analysis}

Bibliographic coupling is a type of relationship definition used to establish a similarity relationship between publications. It occurs when two studies refer to the same study in their references. The result of bibliometric coupling analysis with VOSviewer for 33 countries created from tertiary study data can be seen in Figure 7, and Table 7 shows bibliographic coupling clusters by country. The size of the nodes in the figure increases in proportion to the number of citations. According to the total connection power calculated as a result of bibliographic coupling analysis, it is seen that the most active five countries are Brazil, Germany, Finland, Malaysia, and Pakistan, respectively. Brazil combines the two largest clusters as the center of this analysis. Five of the six most central countries that follow Brazil are seen to be in Europe.

Figure 8 shows the results of bibliographic coupling analysis for 133 institutions. According to the connection power, the five most active institutions are Pontifical Catholic U. of Rio Grande do Sul (Brazil), Blekinge Institute of Technology from Sweden, University of Sao Paulo (Brazil), Pontifical Catholic University of Peru (Peru), and COMSATS Institute of Inf. Technology (Pakistan).

Institutions in bibliographic coupling include institutions from Brazil, Sweden, Peru, Finland and the Netherlands. On the other hand, Brazil, Germany, Finland, Malaysia, and Pakistan are in the first places in the country-based analysis. 
Table 2. Distribution of publications according to sources.

\begin{tabular}{|c|c|c|}
\hline Source of Publication & Type & $\begin{array}{l}\text { Total } \\
\text { Publications }\end{array}$ \\
\hline Information and Software Technology & Journal & 12 \\
\hline ACM International Conference Proceeding Series & Conference & 9 \\
\hline $\begin{array}{l}\text { Lecture Notes in Computer Science (including subseries Lecture } \\
\text { Notes in Artificial Intelligence and Lecture Notes in Bioinformatics) }\end{array}$ & Conference & 7 \\
\hline Journal of Software: Evolution and Process & Journal & 5 \\
\hline Communications in Computer and Information Science & Journal & 4 \\
\hline CEUR Workshop Proceedings & Conference & 3 \\
\hline $\begin{array}{l}\text { Proceedings of the International Conference on Software } \\
\text { Engineering and Knowledge Engineering, SEKE }\end{array}$ & Conference & 3 \\
\hline $\begin{array}{l}2016 \text { 3rd International Conference on Computer and Information } \\
\text { Sciences, ICCOINS } 2016 \text { - Proceedings }\end{array}$ & Conference & 2 \\
\hline Advances in Intelligent Systems and Computing & Journal & 2 \\
\hline Journal of Systems and Software & Journal & 2 \\
\hline
\end{tabular}

Table 3. Distribution of publications according to the subject areas covered.

\begin{tabular}{|l|c|}
\hline Subject Area & Total Publications \\
\hline Agile practices & 25 \\
\hline Agile and management areas & 13 \\
\hline Agile and global or distributed software engineering & 9 \\
\hline Agile and usability & 7 \\
\hline Agile transformation & 6 \\
\hline Agile methodologies & 6 \\
\hline Agile and organization & 6 \\
\hline Advantages and disadvantages of the agile method, challenges and critical areas & 6 \\
\hline Agile cost / effort calculation & 5 \\
\hline Agile and CMMI & 3 \\
\hline Agile human and social reviews & 3 \\
\hline Agile and sustainability & 2 \\
\hline Agile product line engineering & \\
\hline Agile and embedded systems & 1 \\
\hline
\end{tabular}

Table 4. The most active researchers.

\begin{tabular}{|l|l|l|l|}
\hline Researcher & $\begin{array}{l}\text { Number of } \\
\text { Researcher } \\
\text { Citations }\end{array}$ & $\begin{array}{l}\text { Number of } \\
\text { Publications }\end{array}$ & Affiliations \\
\hline Rafael Prikladnicki & 20 & 3 & $\begin{array}{l}\text { School of Technolog, Pontifícia } \\
\text { Universidade Católica do Rio Grande do } \\
\text { Sul, Brazil }\end{array}$ \\
\hline Mirko Perkusich & 9 & 3 & $\begin{array}{l}\text { Department of Computing and Systems, } \\
\text { Federal University of Campina Grande } \\
\text { Brazil }\end{array}$ \\
\hline Siffat Ullah Khan & 3 & 3 & $\begin{array}{l}\text { Department of Computer Science \& IT, } \\
\text { University of Malakand, Pakistan }\end{array}$ \\
\hline Nasir Rashid & 3 & 3 & $\begin{array}{l}\text { Department of Computer Science and } \\
\text { Information Technology, University of } \\
\text { Malakand, Lower Dir, Pakistan }\end{array}$ \\
\hline Edna Dias Canedo & 1 & 3 & $\begin{array}{l}\text { Computer Science Department, University } \\
\text { of Brasília -, Brazil; }\end{array}$ \\
\hline $\begin{array}{l}\text { Ruyther Parente da } \\
\text { Costa }\end{array}$ & 1 & 3 & $\begin{array}{l}\text { Computer Science Department, University } \\
\text { of Brasília -, Brazil; }\end{array}$ \\
\hline
\end{tabular}




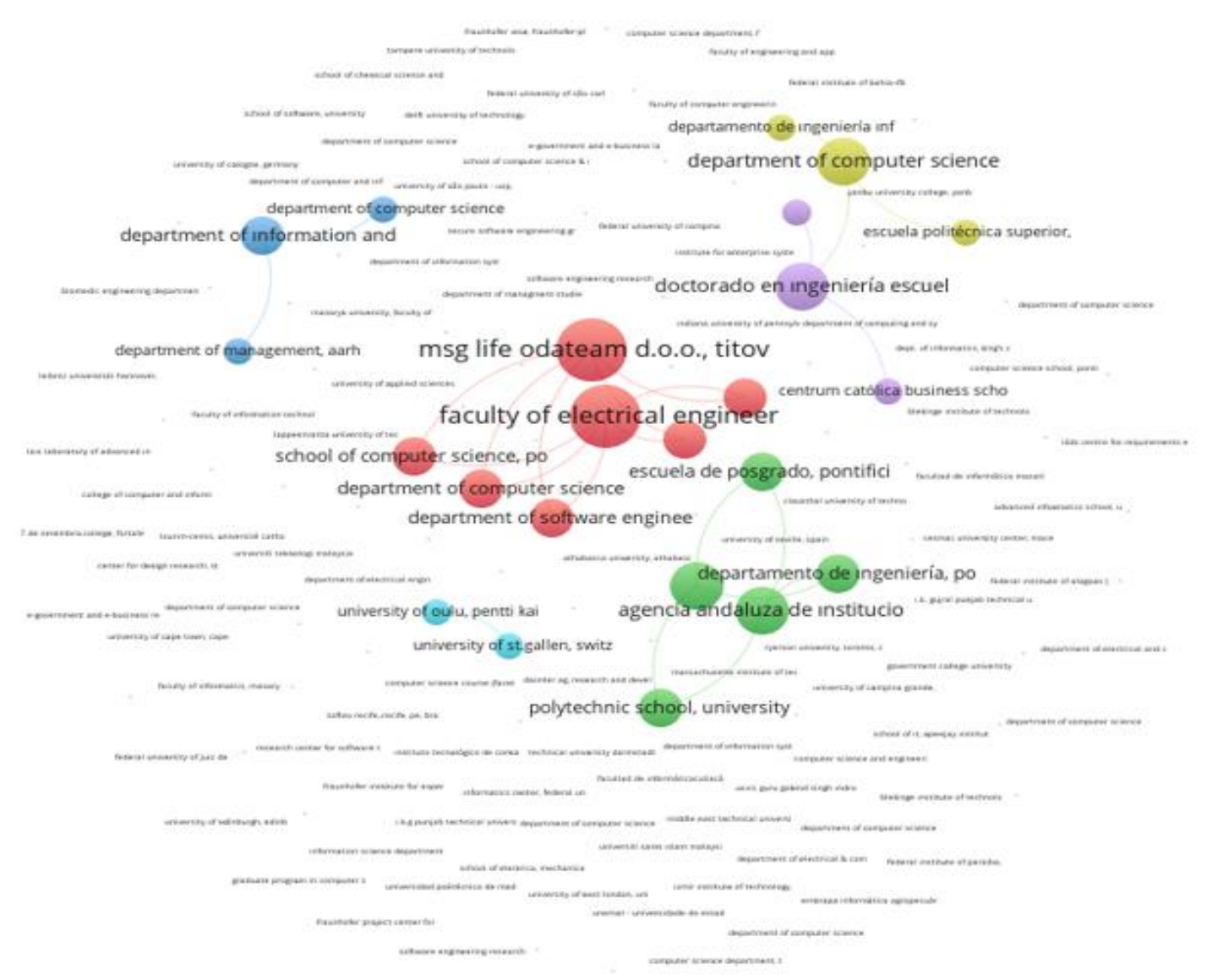

Figure 4. Social network visualization of institutions based on the citation analysis.

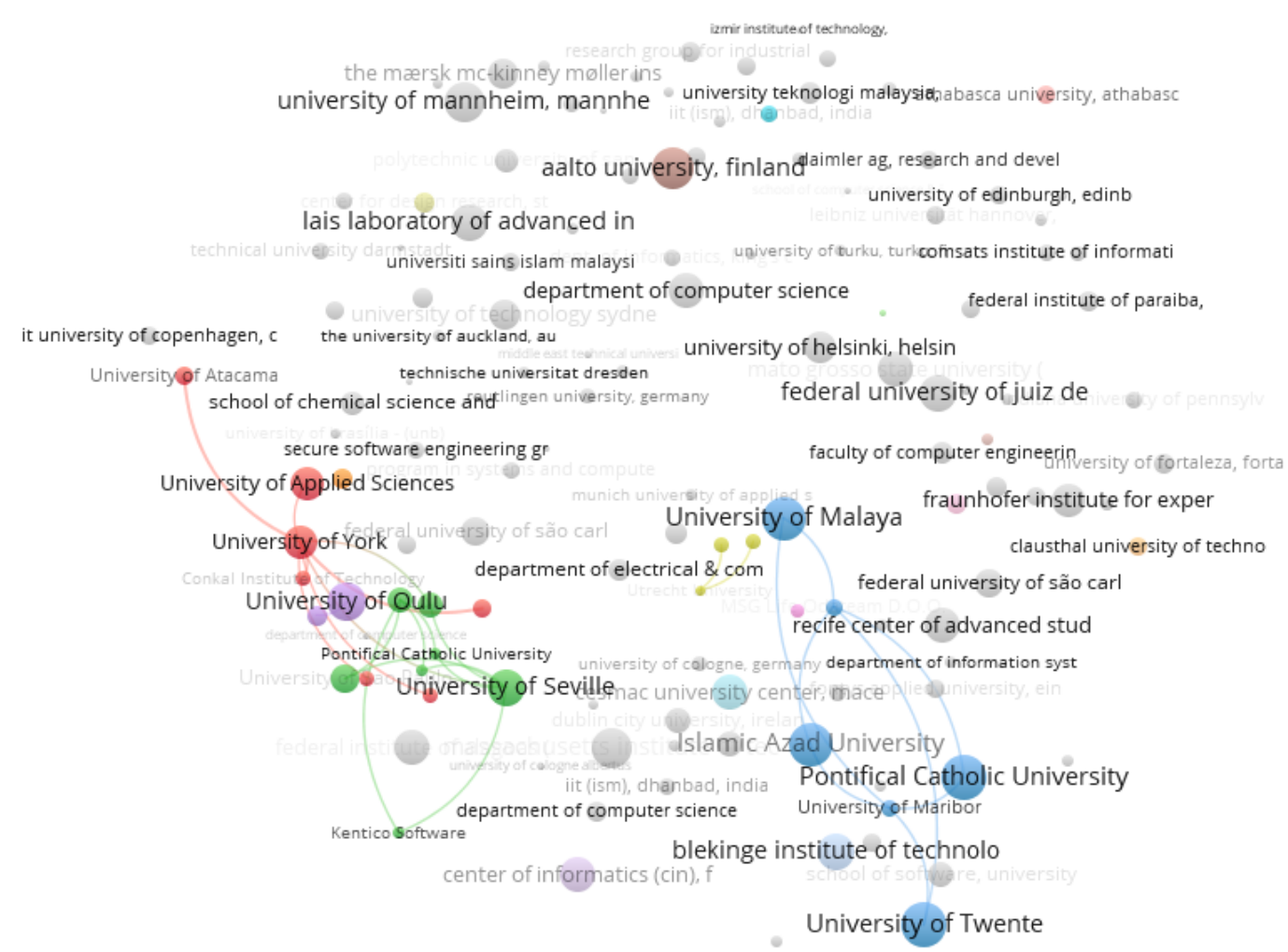

Figure 5. Social network visualization of universities based on the citation analysis. 
Table 5. Citation clusters by institutions.

\begin{tabular}{|l|l|l|}
\hline Cluster 1 & Cluster 2 & Cluster 3 \\
\hline $\begin{array}{l}\text { Departamento De Ingeniería } \\
\text { Informática Y Ciencias De La } \\
\text { Computación, Universidad De } \\
\text { Atacama, Copiapó, Chile }\end{array}$ & $\begin{array}{l}\text { Agencia Andaluza De } \\
\text { Instituciones } \\
\text { Culturales, Junta De } \\
\text { Andalucía, Spain }\end{array}$ & $\begin{array}{l}\text { Department Of Computer Science, } \\
\text { Chalous Branch, Islamic Azad } \\
\text { University (Iau, Chalous, Mazandaran, } \\
\text { 46615-397, Iran }\end{array}$ \\
\hline $\begin{array}{l}\text { Department Of Computer Science, } \\
\text { University Of York, York, United } \\
\text { Kingdom }\end{array}$ & $\begin{array}{l}\text { Escuela De Posgrado, } \\
\text { Pontificia Universidad } \\
\text { Católica Del Perú, } \\
\text { Lima, Peru }\end{array}$ & $\begin{array}{l}\text { Faculty Of Electrical Engineering And } \\
\text { Computer Science, University Of } \\
\text { Maribor, Smetanova 17, Maribor, 2000, } \\
\text { Slovenia }\end{array}$ \\
\hline $\begin{array}{l}\text { Escuela Politécnica Superior, } \\
\text { Universidad Autónoma De Madrid, } \\
\text { Madrid, Spain }\end{array}$ & $\begin{array}{l}\text { Kentico, Brno, Czech } \\
\text { Republic }\end{array}$ & $\begin{array}{l}\text { Msg Life Odateam D.o.o., Titova 8, } \\
\text { Maribor, 2000, Slovenia }\end{array}$ \\
\hline $\begin{array}{l}\text { Lappeenranta University Of } \\
\text { Technology (Lut), P.O Box 20, } \\
\text { Lappeenranta, F1-53851, Finland }\end{array}$ & $\begin{array}{l}\text { Masaryk University, } \\
\text { Brno, Czech Republic }\end{array}$ & $\begin{array}{l}\text { Pontifícia Universidade Católica Do } \\
\text { Rio Grande Do Sul, Porto-Alegrers, } \\
\text { Brazil }\end{array}$ \\
\hline $\begin{array}{l}\text { Universidad Politécnica De Madrid, } \\
\text { Campus De Montegancedo, Boadilla } \\
\text { Del Monte, 28660, Spain }\end{array}$ & $\begin{array}{l}\text { Pontificia Universidad } \\
\text { Católica Del Perú, } \\
\text { Lima, Peru }\end{array}$ & University Of Malaya, Malaysia \\
\hline $\begin{array}{l}\text { University Of Applied Sciences } \\
\text { Emden/Leer, Emden, Germany }\end{array}$ & $\begin{array}{l}\text { University Of Sao } \\
\text { Paulo, Sao Paulo, Brazil }\end{array}$ & $\begin{array}{l}\text { University Of Twente, Enschede, } \\
\text { Netherlands }\end{array}$ \\
\hline $\begin{array}{l}\text { Instituto Tecnológico De Conkal, Km } \\
\text { 16 Oldroadmotul Yucatán, Mexico }\end{array}$ & $\begin{array}{l}\text { University Of Seville, } \\
\text { Spain }\end{array}$ & \\
\hline & & Cluster 5 \\
\hline $\begin{array}{l}\text { Cluster 4 } \\
\text { Department Of Computer Science, } \\
\text { Aalborg University, Denmark }\end{array}$ & $\begin{array}{l}\text { University Of Oulu, } \\
\text { Finland }\end{array}$ & \\
\hline $\begin{array}{l}\text { Department Of Management, Aarhus } \\
\text { University, Denmark }\end{array}$ & $\begin{array}{l}\text { University Of St.Gallen, } \\
\text { Switzerland }\end{array}$ & \\
\hline $\begin{array}{l}\text { Department Of Information And } \\
\text { Computer Science, Utrecht } \\
\text { University, Utrecht, Netherlands }\end{array}$ & & \\
\hline
\end{tabular}

Table 6. Citation clusters by universities.

\begin{tabular}{|l|l|l|l|l|}
\hline Cluster 1 & Cluster 2 & Cluster 3 & Cluster 4 & Cluster 5 \\
\hline University of Atacama & $\begin{array}{l}\text { Agencia Andaluza de } \\
\text { Instituciones Culturales }\end{array}$ & $\begin{array}{l}\text { Islamic Azad } \\
\text { University }\end{array}$ & $\begin{array}{l}\text { Aalborg } \\
\text { University }\end{array}$ & $\begin{array}{l}\text { University of } \\
\text { Oulu }\end{array}$ \\
\hline University of York & $\begin{array}{l}\text { Pontifical Catholic } \\
\text { University of Peru }\end{array}$ & $\begin{array}{l}\text { University of } \\
\text { Maribor }\end{array}$ & $\begin{array}{l}\text { Aarhus } \\
\text { university }\end{array}$ & $\begin{array}{l}\text { University of } \\
\text { St.Gallen }\end{array}$ \\
\hline $\begin{array}{l}\text { Autonomous University } \\
\text { of Madrid }\end{array}$ & Kentico Software & $\begin{array}{l}\text { MSG Life Odateam } \\
\text { D.O.O. }\end{array}$ & $\begin{array}{l}\text { Utrecht } \\
\text { University }\end{array}$ & \\
\hline $\begin{array}{l}\text { Lappeenranta University } \\
\text { of Technology }\end{array}$ & Masaryk University & $\begin{array}{l}\text { Pontifical Catholic } \\
\text { University of Rio } \\
\text { Grande do Sul }\end{array}$ & & \\
\hline $\begin{array}{l}\text { Technical University of } \\
\text { Madrid }\end{array}$ & $\begin{array}{l}\text { Pontifical Catholic } \\
\text { University of Peru }\end{array}$ & $\begin{array}{l}\text { University of } \\
\text { Malaya }\end{array}$ & & \\
\hline $\begin{array}{l}\text { University of Applied } \\
\text { Sciences Emden/Leer }\end{array}$ & University of Sao Paulo & $\begin{array}{l}\text { University of } \\
\text { Twente }\end{array}$ & & \\
\hline $\begin{array}{l}\text { Conkal Institute of } \\
\text { Technology }\end{array}$ & University of Seville & & & \\
\hline
\end{tabular}




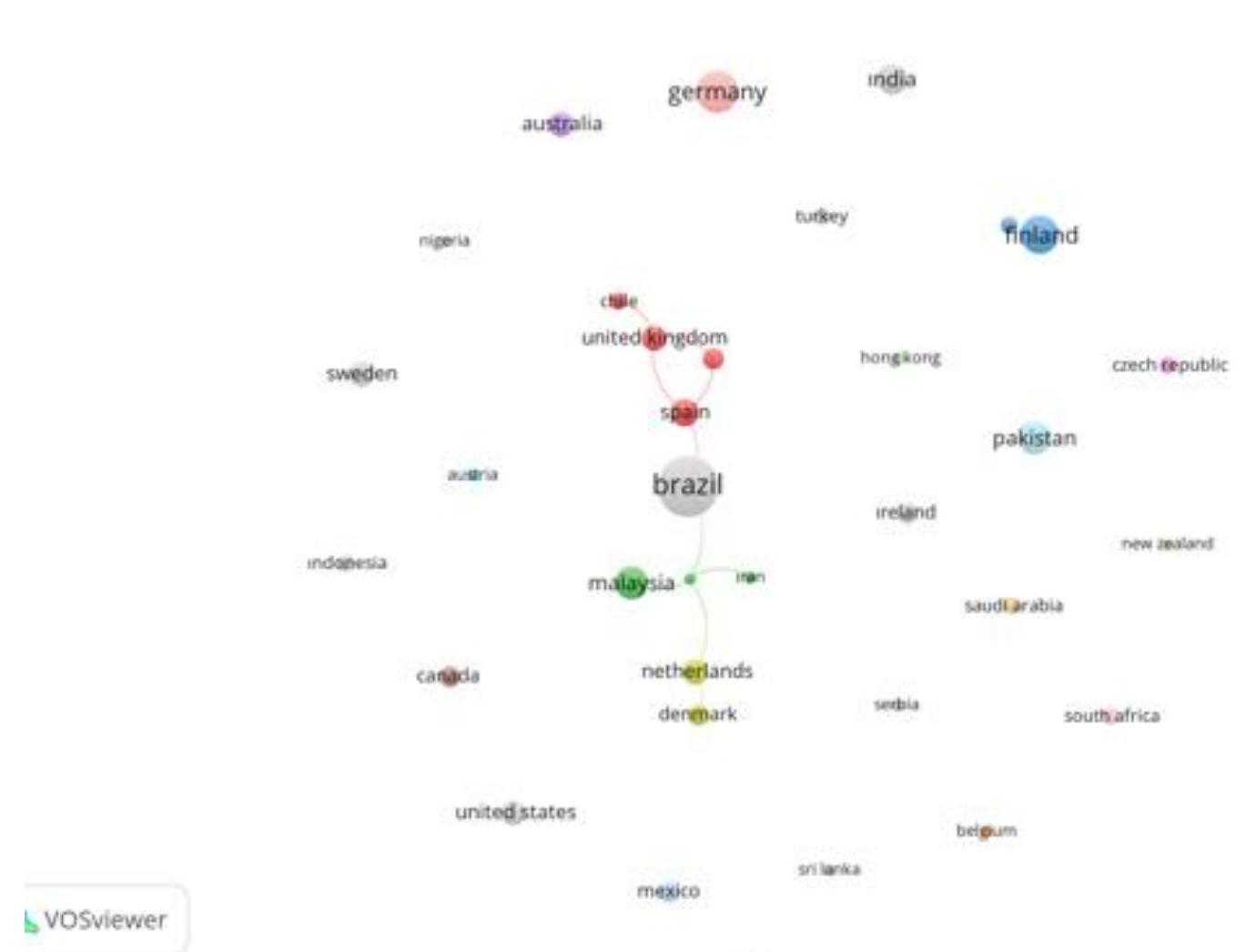

Figure 6. Citation analysis of countries.

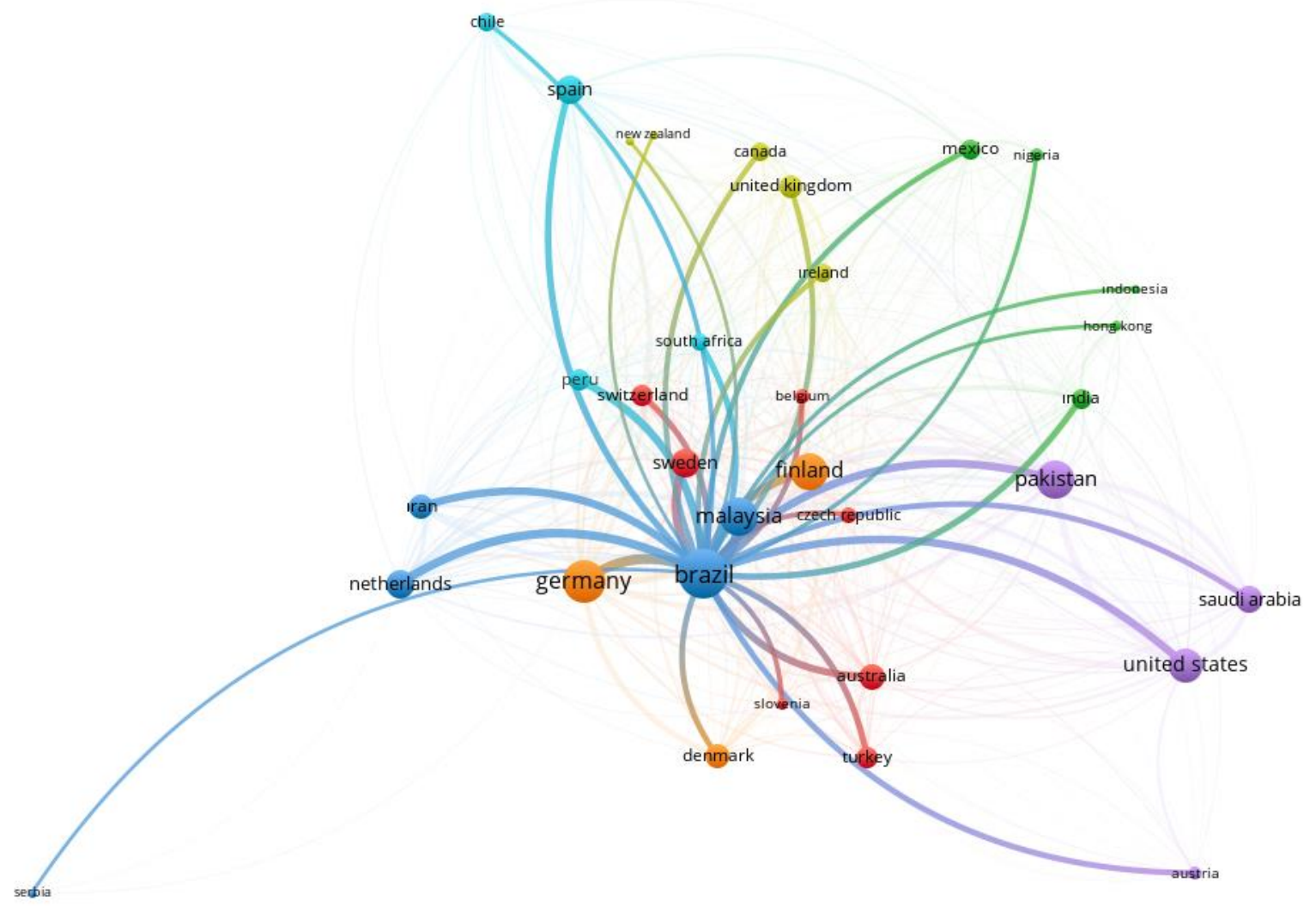

Figure 7. The most active countries of bibliographic coupling analysis. 
Table 7. Bibliographic coupling clusters by country.

\begin{tabular}{|l|l|l|l|l|l|}
\hline Cluster 1 & Cluster 2 & Cluster 3 & Cluster 4 & Cluster 5 & Cluster 6 \\
\hline Belgium & Australia & Chile & Austria & Denmark & Iranian \\
\hline Canada & Brazil & Peru & Pakistan & Finland & Malaysia \\
\hline Hong Kong & Czechia & South Africa & Saudi Arabia & Germany & Netherlands \\
\hline India & Slovenia & Spain & USA & & \\
\hline Indonesia & Sweden & & & & \\
\hline Ireland & Switzerland & & & & \\
\hline Mexican & Turkey & & & & \\
\hline New Zealand & & & & & \\
\hline Nigeria & & & & & \\
\hline Serbia & & & & & \\
\hline Sri lanka & & & & & \\
\hline United Kingdom & & & & & \\
\hline
\end{tabular}

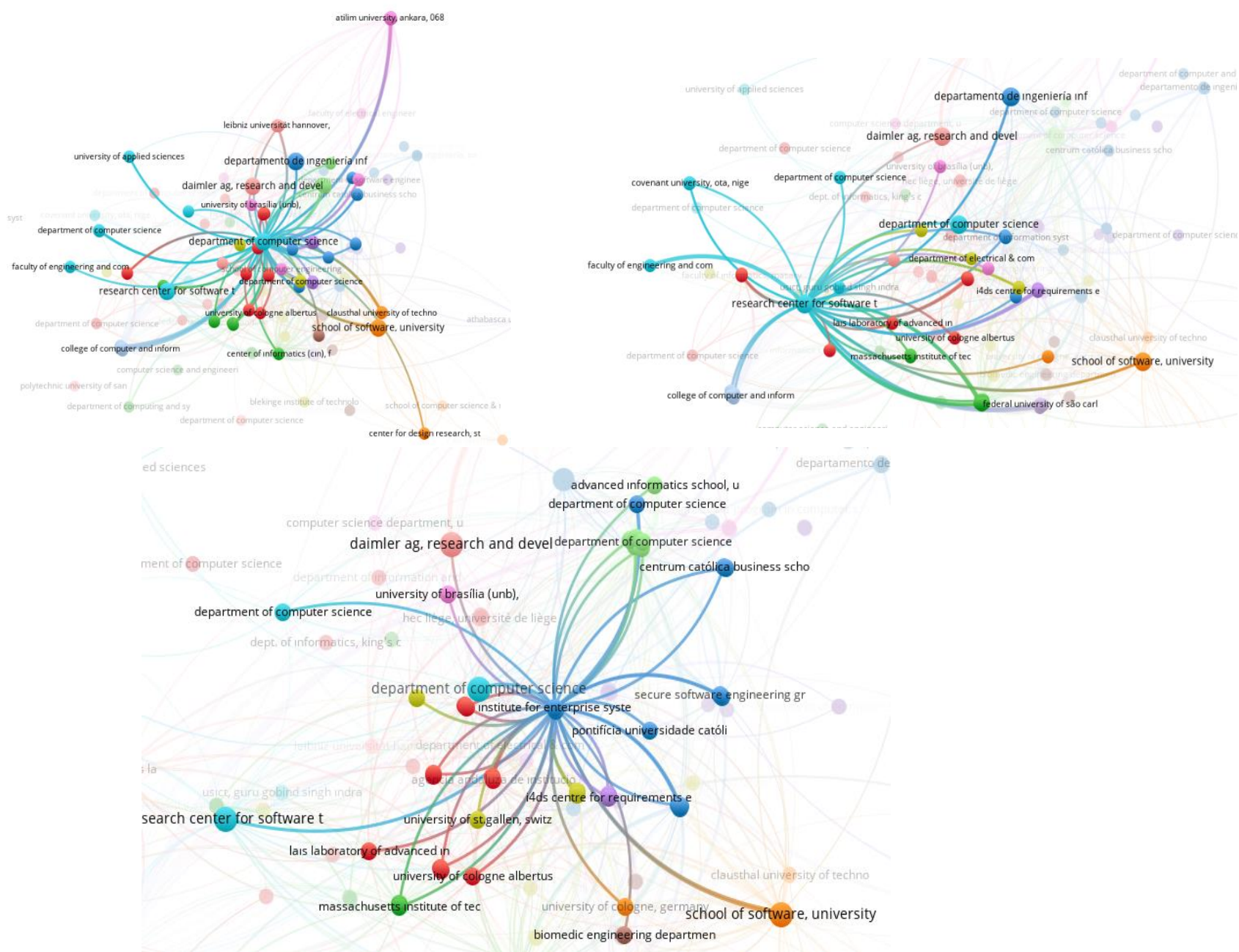

Figure 8. The most active institutions of bibliographic coupling analysis. 


\section{CONCLUSION}

Agile software development, which is increasingly used worldwide, is growing steadily, increasing its reputation and active role in the industry. In this study, a tertiary study from literature reviews on agile software development was conducted and social network analysis was performed with the dataset created by the researchers from the tertiary study.

According to the results of our study, the most active sources according to the number of publications were determined as Information and Software Technology and ACM International Proceeding Series. Information and Software Technology is a journal that deals with systematic literature reviews, and we were inspired by Kitchenham et al.'s 2010 study on it [17]. ACM, on the other hand, is a reputable database that is used by most of the reviewed literature reviews. The scope of the studies reviewed was mostly on agile practices and management areas. Embedded systems, product line engineering, and human and social studies were the least explored topics.

Our study has some limitations that may affect its usefulness. First, our study covered the SLRs on agile software development published between 2013 and 2018. It can further be extended to include the SLRs published since 2018 and can present a more comprehensive view of the field. Second, the term "agile" is an umbrella term that can be too broad to cover the practices applied in software engineering. Rather than using this term as part of the search keys in SLR research, more focused literature reviews can be conducted using related but more specific search terms like "extreme programming", "scrum", "lean", and so on.

The combination of tertiary study and social network increased the power of the study and presented a different perspective for the subject. The findings obtained within the scope of the study can be used for various purposes. For example, they can be used to determine an invited speaker related to the subject at a conference. In addition, they can be used to determine which universities are prominent in a special research field. Moreover, they can be helpful for finding institutions that will partner to work in international university-based studies, or for forming a team on a research subject.

\section{REFERENCES}

[1] Kitchenham, B. (2004). Procedures for Performing Systematic Reviews, Report Department of Computer Science, Keele University, UK.

[2] Kitchenham, B., \& Charters, S. (2007). Guidelines for performing Systematic Literature Reviews in Software Engineering, Report Keele University and Durham University.
[3] Tunalı, V. (2016). Sosyal Ă̆ Analizine Giriş. Ankara, Türkiye: Nobel Akademik Yayıncılık.

[4] Hoda, R., Kruchten, P., Noble, J., \& Marshall, S. (2010). Agility in context. Proceedings of the ACM international conference on Object oriented programming systems languages and applications, Reno, NV, October 17.

[5] Hoda, R., Salleh, N., Grundy, J., \& Tee, H. M. (2017). Systematic literature reviews in agile software development: A tertiary study. Information and Software Technology, 85, 6070.

[6] Dikert, K., Paasivaara, M., \& Lassenius, C. (2016). Challenges and success factors for largescale agile transformations: A systematic literature review. Journal of Systems and Software, 119, 87-108.

[7] Boehm, B. (2002). Get ready for agile methods, with care. Computer, 35(1), 64-69.

[8] Moe, N. B., Dingsøyr, T., \& Dybå, T. (2010). A teamwork model for understanding an agile team: A case study of a Scrum project. Information and Software Technology, 52(5), 480-491.

[9] Janzen, D., \& Saiedian, H. (2005). Test-driven development concepts, taxonomy, and future direction. Computer, 38(9), 43-50.

[10] Aggarwal, V., \& Singhal, A. (2019). Empirical study of test driven development with scrum. $3^{\text {rd }}$ International Conference on Advances in Computing and Data Sciences, Ghaziabad, India, April 12-13.

[11] Alam, S., Nazir, S., Asim, S., \& Amr, D. (2017). Impact and challenges of requirement engineering in agile methodologies: A systematic review. Int. J. Adv. Comput. Sci. Appl, 8(4), 411-420.

[12] Schön, E.-M., Winter, D., Escalona, M. J., \& Thomaschewski, J. (2017). Key challenges in agile requirements engineering. $18^{\text {th }}$ International Conference on Agile Software Development, Cologne, Germany, May 22-26.

[13] Jalali, S., \& Wohlin, C. (2012). Global software engineering and agile practices: a systematic review. Journal of software: Evolution and Process, 24(6), 643-659.

[14] Silva, F. S., Soares, F. S. F., Peres, A. L., de Azevedo, I. M., Vasconcelos, A. P. L., Kamei, F. K., \& de Lemos Meira, S. R. (2015). Using CMMI together with agile software development: A systematic review. Information and Software Technology, 58, 20-43.

[15] Xu, X., Chen, X., Jia, F., Brown, S., Gong, Y., \& Xu, Y. (2018). Supply chain finance: A systematic literature review and bibliometric analysis. International Journal of Production Economics, 204, 160-173.

[16] Inamdar, Z., Raut, R., Narwane, V. S., Gardas, B., Narkhede, B., \& Sagnak, M. (2020). A systematic literature review with bibliometric 
analysis of big data analytics adoption from period 2014 to 2018. Journal of Enterprise Information Management, 34(1), 101-139.

[17] Kitchenham, B., Pretorius, R., Budgen, D., Pearl Brereton, O., Turner, M., Niazi, M., \& Linkman, S. (2010). Systematic literature reviews in software engineering - A tertiary study. Information and Software Technology, 52(8), 792-805.

[18] Bartolacci, F., Caputo, A., \& Soverchia, M. (2020). Sustainability and financial performance of small and medium sized enterprises: A bibliometric and systematic literature review. Business Strategy and the Environment, 29(3), 1297-1309.

[19] Database of Abstracts of Reviews of Effects (DARE). (2008). In: Encyclopedia of Public Health, W. Kirch (Ed.). Dordrecht: Springer Netherlands.

[20] Bayram, E., Doğan, B., \& Tunalı, V. (2020). Bibliometric Analysis of the Tertiary Study on Agile Software Development using Social Network Analysis. 2020 Innovations in
Intelligent Systems and Applications Conference (ASYU), Istanbul, Turkey, October 15-17.

[21] Chinowsky, P., \& Taylor, J. E. (2012). Networks in engineering: an emerging approach to project organization studies. Engineering Project Organization Journal, 2(1-2), 15-26.

[22] Eck, N. J. v., \& Waltman, L. (2014). Visualizing Bibliometric Networks. In: Measuring Scholarly Impact, Y. Ding, R. Rousseau \& D. Wolfram (Eds.). Switzerland: Springer, Cham, 285-320.

[23] Bastian, M., Heymann, S., \& Jacomy, M. (2009). Gephi: An Open Source Software for Exploring and Manipulating Networks. International AAAI Conference on Weblogs and Social Media, San Jose, California, USA, May 17-20.

[24] Pilkington, A., \& Meredith, J. (2009). The evolution of the intellectual structure of operations management-1980-2006: A citation/co-citation analysis. Journal of Operations Management, 27(3), 185-202.

[25] Kessler, M. M. (1963). Bibliographic coupling between scientific papers. American Documentation, 14(1), 10-25. 